\title{
Hubungan Peran Serta Kader Posyandu dalam Pelaksanaan Pemberian Imunisasi Dasar Lengkap
}

\section{Yuni Kurniati}

Akademi Kebidanan Budi Mulia Palembang

\section{Informasi Artikel :}

Diterima : 30 April 2020

Direvisi : 10 Mei 2020

Disetujui : 19 Mei 2020

*Korespondensi Penulis : yunikurniati80@gmail.com

\begin{abstract}
A B S T R A K
Kader Posyandu memiliki peran yang strategis dalam memberikan edukasi mengenai kesehatan kepada masyarakat. Posyandu merupakan sarana yang dapat digunakan untuk upaya pencegahan dan penanggulangan masalah kesehatan terutama kesehatan ibu dan anak. Pos pelayanan terpadu (Posyandu) merupakan perpanjangan tangan Puskesmas yang memberikan pelayanan dan pemantauan kesehatan yang dilaksanakan secara terpadu. Dalam kegiatan Posyandu salah satunya adalah memberikan imunisasi. Imunisasi adalah upaya untuk menimbulkan atau meningkatkan kekebalan seseorang secara aktif terhadap suatu penyakit. Penelitian ini menggunakan jenis penelitian observasional analitik dengan desain penelitian Cross-Sectional. Lokasi penelitian ini adalah Posyandu di Perumahan Griya Interbis Indah. Pengambilan data dilakukan pada bulan Februari 2020. Data dikumpulkan dari 60 ibu yang memiliki anak berusia 12-23 bulan. Metode pengambilan sampel dengan random sampling. Dari hasil penelitian diketahui "Ada hubungan bermakna antara peran serta kader Posyandu dalam pemberian Imunisasi Dasar Lengkap di wilayah perumahan Griya Interbis Indah". Hal ini menunjukkan keberadaan kader Posyandu yang dekat dengan masyarakat dapat menjadi motivator bagi para ibu untuk dapat membawa anaknya untuk diberikan Imunisasi Dasar Lengkap.
\end{abstract}

\section{Kata Kunci : Imunisasi Dasar Lengkap, Kader Posyandu}

\begin{abstract}
Posyandu cadres have a strategic role in providing education about health to the community. Posyandu is a facility that can be used to prevent and overcome health problems, especially maternal and child health. Integrated service post (Posyandu) is an extension of Puskesmas that provides integrated health and monitoring services. In Posyandu activities one of them is giving immunizations. Immunization is an attempt to actively induce or increase a person's immunity against a disease. This research uses analytic observational research with cross-sectional research design. The location of this research is Posyandu in Griyalnterbis Indah Housing. Data was collected in February 2020. Data was collected from 60 mothers who had children aged 12-23 months. The method of sampling is random sampling. From the results of the study note "There is a significant relationship between the role of Posyandu cadres in the provision of Complete Basic Immunization in GriyaInterbis Indah residential area". This shows the existence of Posyandu cadres who are close to the community can be a motivator for mothers to be able to bring their children to be given Complete Basic Immunization.
\end{abstract}

Keywords: Complete Basic Immunization, Posyandu Cadre 


\section{PENDAHULUAN}

Peraturan menteri kesehatan no. 8 tahun 2019 tentang pemberdayaan masyarakat bidang kesehatan, bahwa dalam rangka melaksanakan pembangunan kesehatan diperlukan upaya peningkatan pemberdayaan masyarakat bidang kesehatan yang terintegrasi dan bersinergi dengan bidang lainnya sesuai kewenangan di berbagai tingkat pemerintahan.Kaderpemberdayaan masyarakat bidang kesehatan yang selanjutnya disebut kader adalah setiap orang yang dipilih oleh masyarakat dan dilatih untuk menggerakkan masyarakat berpartisipasi dalam pemberdayaan masyarakat bidang kesehatan. Kegiatan pemberdayaan masyarakat dilaksanakan dengan mengutamakan pendekatan promotif dan preventif. $^{1}$

Kader Posyandu memiliki peran yang strategis dalam memberikan edukasi mengenai kesehatan kepada masyarakat. Posyandu merupakan sarana yang dapat digunakan untuk upaya pencegahan dan penanggulangan masalah kesehatan terutama kesehatan ibu dan anak ${ }^{2}$. Pos pelayanan terpadu (Posyandu) merupakan perpanjangan tangan Puskesmas yang memberikan pelayanan dan pemantauan kesehatan yang dilaksanakan secara terpadu ${ }^{3}$.

Banyak faktor yang mempengaruhi keaktifan kader, diantaranya pengetahuan kader tentang Posyandu, pengetahuan kader tentang Posyandu akan berpengaruh terhadap kemauan dan perilaku kader untuk mengaktifkan kegiatan Posyandu, sehingga akan mempengaruhi terlaksananya program kerja Posyandu. Perilaku yang didasari pengetahuan akan lebih langgeng daripada perilaku yang tidak didasari oleh pengetahuan. ${ }^{4}$

Dalam kegiatan Posyandu salah satunya adalah memberikan imunisasi. Imunisasi adalah upaya untuk menimbulkan atau meningkatkan kekebalan seseorang secara aktif terhadap suatu penyakit sehingga bila suatu saat terpajan dengan penyakit tersebut maka tidak mengalami sakit atau hanya mengalami penyakit ringan disebabkan kekebalan tubuh seseorang tersebut telah memiliki antibodi untuk melawan penyakit tersebut. Vaksin adalah produk biologi yang berisi antigen berupa mikroorganisme yang sudah mati atau masih hidup yang dilemahkan, masih utuh atau bagiannya, atau berupa toksin mikroorganisme yang telah diolah menjadi toksoid atau protein rekombinan, yang ditambahkan dengan zat lainnya yang bisa diberikan kepada seseorang akan menimbulkan kekebalan spesifik secara aktif terhadap penyakit tertentu. Imunisasi program adalah imunisasi yang diwajibkan kepada seseorang sebagai bagian dari masyarakat dalam rangka melindungi yang bersangkutan dan masyarakat sekitarnya dari penyakit yang dapat dicegah dengan imunisasi. $^{5}$

Sebanyak 2/3 kematian bayi (neonatus) terjadi karena komplikasi kejadian intrapartum (28,3\%), gangguan respiratori dan kardiovaskuler $(21,3 \%)$, BBLR dan prematur (19\%), kelainan konginetal $(14,8 \%)$, infeksi $(7,3 \%)^{6}$.Masih ada kasus sporadis dan KLB (Difteri, campak, Polio) sehingga perlu meningkatkan cakupan imunisasi melalui peningkatan kegiatan luar gedung dan perbaikan pencatatan/monitoring (penggunaan PWS imunisasi), untuk mencapai Universal Child Immunization (UCI) pada seluruh kabupaten/kota sampai level desa/kelurahan dan meningkatkan mutu imunisasi melalui perbaikan rantai dingin (cold chain) dan peningkatan kapasitas SDM Imunisasi. Persentase imunisasi dasar lengkap pada anak usia 12 - 23 bulan sebesar 57,9\% ${ }^{6}$,sedangkan angka kematian bayi (per $1000 \mathrm{KH}$ ) sebesar $24^{7}$.

Di Indonesia angka kematian bayi menurut hasil SUPAS 2015 adalah sebesar 22 bayi per 1000 kelahiran hidup. Angka tersebut mengalami penurunan dari hasil sensus penduduk yang dilaksanakan sebelumnya. Hasil SUPAS 2015 juga menunjukkan angka kematian anak sebesar 4 anak per 1000. Angka kematian anak pada tahun 2015 sebesar 4,03 yang artinya terdapat sekitar 4 anak umur 1-4 tahun yang meninggal per 1000 anak pada umur yang sama. Sedangkan Angka Kematian Balita yang mencakup kematian bayi dan kematian anak hasil SUPAS 2015 adalah 26 per 1000 Balita. Hasil SUPAS 2015 menunjukkan angka kematian balita sebesar 25,74 yang artinya terdapat sekitar 26 anak umur o sampai 4 tahun yang meninggal per 1000 anak pada umur yang sama. ${ }^{8}$

Pencapaian cakupan imunisasi dasar lengkap pada 2018 di Sumatera Selatan mampu mencapai angka rata - rata setiap kabupaten kota 99,4\%, melebihi target yang telah ditetapkan sebesar $95 \%$.Di Sumatera Selatan [Sumsel], Perkembangan Imunisasi patut untuk diapresiasi, pasalnya, menurut data Dinas Kesehatan (Dinkes) Sumsel, tentang pencapaian cakupan imunisasi dasar lengkap pada 2018, mampu mencapai angka rata - rata setiap kabupaten kota, yakni $99,4 \%$, melebihi target yang telah ditetapkan, yakni $95 \%$. Beberapa hal yang menjadi kendala, yakni terkadang waktu yang tidak tepat, antara 
masyarakat dan tim di lapangan, sehingga terasa sulit untuk bertemu, yang kedua, yakni ada seolah kejadian - kejadian tersiar atau berita miring, seolah imunisasi berdampak negatif oleh masyarakat, berdampak kekhawatiran bagi masyarakat. ${ }^{9}$

Program Imunisasi merupakan salah satu program prioritas dalam pembangunan kesehatan yang berperan penting dalam upaya menurunkan angka kematian bayi (AKB), sebagai salah satu indikator utama keberhasilan pembangunan kesehatan. Beberapa penyakit yang dapat dicegah dengan imunisasi (PD3I) antara lain difteri, pertusis, tetanus, tuberculosis, campak, poliomyelitis, hepatitis B, meningitis meningokokus, dan demam kuning (yellow fever).Salah satu upaya pencegahan terhadap penyakit menular dilakukan dengan memberikan imunisasi lengkap. Pemberian imunisasi lengkap dilakukan oleh tenaga kesehatan dari puskesmas yang menaungi Posyandu di wilayah kerjanya masing-masing. Dalam pelaksanaanya, terdapat kader Posyandu yang telah mendapatkan pelatihan dalam berbagai masalah kesehatan terutama kesehatan ibu dan anak, salah satunya bagaimana memberikan penyuluhan kepada masyarakat tentang pemberian imunisasi dan membantu tenaga medis dalam pelaksanaan pemberian imunisasi di Posyandu. Dalam pelaksanaannya di lapangan, diketahui bahwa tidak semua kader Posyandu memiliki kemampuan dan keterampilan untuk memberikan edukasi mengenai kesehatan kepada masyarakat.

Sehingga berdasarkan hal tersebut, peneliti tertarik untuk mengetahui hubungan peran serta kader Posyandu dalam pelaksanaan pemberian imunisasi dasar lengkap di wilayah kerja Posyandu di Perumahan Griya Interbis Indah. Sedangkan tujuan penelitian ini untuk mengetahui seberapa besar potensi peran serta kader Posyandudalam pelaksanaan imunisasi dasar lengkap padaPosyandu di Perumahan Griya Interbis Indah.

\section{METODE PENELITIAN}

Penelitian ini menggunakan jenis penelitian observasional analitik dengan desain penelitian Cross-Sectional. Lokasi penelitian ini adalah Posyandu di Perumahan Griya Interbis Indah. Pengambilan data dilakukan pada bulan Februari 2020. Data dikumpulkan dari 60 ibu yang memiliki anak berusia 12-23 bulan. Metode pengambilan sampel dengan random sampling. Data dikumpulkan dengan wawancara dan dokumentasi KMS atau buku KIA. Analisis data menggunakan uji regresi logistik dengan $\alpha=$ 0,05 .

\section{HASIL PENELITIAN}

Hasil penelitian mengenai hubungan peran serta kader Posyandu dalam pelaksanaan pemberian imunisasi dasar lengkap di Posyandu yang berada di wilayah Perumahan Griya Interbis Indah dapat dilihat pada tabel 1 .

\section{Tabel 1. hubungan peran serta kader Posyandu dalam pelaksanaan pemberian Imunisasi Dasar Lengkap}

\begin{tabular}{|c|c|c|c|c|c|c|c|}
\hline \multirow{3}{*}{$\begin{array}{l}\text { Peran } \\
\text { Serta } \\
\text { Kader }\end{array}$} & \multicolumn{4}{|c|}{$\begin{array}{c}\text { Status Imunisasi } \\
\text { Dasar }\end{array}$} & \multirow{2}{*}{\multicolumn{2}{|c|}{ Total }} & \multirow{3}{*}{$\begin{array}{c}P \\
\text { Value }\end{array}$} \\
\hline & \multicolumn{2}{|c|}{ Lengkap } & \multicolumn{2}{|c|}{$\begin{array}{c}\text { Tidak } \\
\text { Lengkap }\end{array}$} & & & \\
\hline & $\mathbf{n}$ & $\%$ & $\mathbf{n}$ & $\%$ & $\mathbf{n}$ & $\%$ & \\
\hline $\begin{array}{l}\text { Ada Peran } \\
\text { Serta Kader }\end{array}$ & 45 & 74,97 & 5 & 8,33 & 50 & 83,33 & \\
\hline $\begin{array}{l}\text { Tidak Ada } \\
\text { Peran serta } \\
\text { Kader }\end{array}$ & 3 & 5,03 & 7 & 11,74 & 10 & 16,67 & 0,000 \\
\hline Total & 48 & 80 & 12 & 20 & 60 & 100 & \\
\hline
\end{tabular}

Pada tabel 1 menunjukkan, dari 60 (100\%) responden yang memilki anak berusia 12 bulan sampai dengan 23 bulan menyatakan bahwa sebanyak 48 responden $(80 \%)$ memilki satus imunisasi dasar Lengkap. Ibu yang menyatakan anaknya belum memperoleh imunisasi dasar lengkap sebanyak 12 responden (20\%). Adanyanya peran serta kader Posyandu diakui oleh 50 responden $(83,33 \%)$, sedangkan yang menyatakan tidak ada peran serta kader Posyandu sebanyak 10 responden $(16,67 \%)$.

Sebanyak 45 responden (74,97\%) mengakui adanya peran serta kader Posyandu dalam memotivasi para ibu untuk memberikan imunisasi dasar lengkap pada buah hatinya. Sedangkan sebanyak 5 responden $(8,33 \%)$ walaupun telah mengakui adanya peran serta kader Posyandu, ternyata tidak memberikan imunisasi dasar lengkap pada anaknya.

Jumlah responden yang menyatakan tidak ada peran serta kader Posyandu dalam memotivasi ibu untuk melaksanakan IDL sebanyak 3 responden $(5,03 \%)$, tetapi ibu tersebut tetap berhasil memberikan imunisasi dasar lengkap kepada anaknya. Terdapat golongan ibu yang menyatakan tidak ada peran serta kader Posyandu dan juga tidak memberikan imunisasi lengkap kepada anaknya sebanyak 7 responden $(11,74 \%)$. 
Hasil analisis data menggunakan uji regresi logistik menunjukkan $p$-value $0,000(\mathrm{p}<0,05)$. Dengan demikian dapat diketahui ada hubungan bermakna antara peran serta kader Posyandu dalam pemberian imunisasi dasar lengkap di wilayah perumahan Griya Interbis Indah.

\section{PEMBAHASAN}

Saat ini imunisasi sangat diperlukan untuk menangkal berbagai penyakit yang berbahaya dan menular dengan cara pemberian vaksin. Vaksin ini memiliki banyak jenis dengan keunggulannya masing-masing dalam mencegah seorang anak terkena penyakit yang dapat membahayakan kehidupannya. Masyarakat dapat memperoleh imunisasi melalui fasiltas kesehatan seperti adanya Posyandu yang memfasilitasi masyarakat di daaerahnya untuk mendapatkan imunisasi bagi anak-anaknya. Peran serta kader Posyandu yang aktif sangat dibutuhkan untuk memberikan masukan dan ilmu pengetahuan mengenai imunisasi dasar lengkap kepada masyarakat. Dikarenakan kader Posyandu merupakan seseorang yang dipilih masyarakat di daerahnya sebagai orang yang diharapkan dapat meningkatkan kesehatan masyarakat.

Sebagai kader Posyandu yang aktif dan dekat dengan masyarakat didaerahnya secara langsung, tentunya memiliki keunggulan tersendiri dalam mengarahkan masyarakat untuk hidup sehat. Seperti halnya mendekati masyarakat yang secara tidak langsung adalah tetangga dari kader Posyandu itu sendiri, sehingga masyarakat merasa lebih dekat dan lebih percaya apapun yang disampaikan oleh kader Posyandu tersebut. Masyarakat rutin memeriksa balitanya, untuk mengukur berat badan bayi, tinggi tubuh bayi, kesehatan fisik secara umum. Terkadang ada hari tertentu diberitahukan kepada masyarakat bahwa terdapat program imunisasi, yang disampaikan melalui surat pemberitahuan ataupun pengeras suara dari masjid. Sehingga, masyarakat dengan antusias datang untuk mengimunisasi bayinya.

Dari hasil penelitian, diketahui dari 60 responden (100\%), sebanyak 48 responden $(80 \%)$ telah malaksanakan imunisasi dasar lengkap. Ini dapat dibuktikan juga dengan data sekunder berupa dokumentasi KMS atau buku KIA. Angka ini menunjukkan masyarakat memiliki kesadaran akan pentingnya melaksanakan imunisasi bagi kesehatan anaknya. Sebanyak 12 responden (20\%) mengaku tidak memberikan imunisasi dasar lengkap, walaupun pada kenyataanya mereka mengetahui pentingnya imunisasi bagi anaknya. Berbagai alasan mereka sampaikan, seperti orang tua sibuk bekerja, memilki anak yang banyak sehingga tidak sempat ke Posyandu, karena saat itu bayinya sedang sakit sehingga tidak dapat diberikan imunisasi.

Ibu yang telah berhasil memberikan imunisasi dasar lengkap pada bayinya dan menyatakan adanya peran serta kader dalam menggalakan imunisasi di perumahan Griya Interbis Indah sebanyak 45 responden $(74,97 \%)$. Para ibu mengaku pernah diberikan penyuluhan mengenai imunisasi dasar lengkap pada saat mereka ke Posyandu, dan pada saat bertemu dengan kader Posyandu di lingkungan masyarakat tempat tinggalnya. Sehingga memotivasi ibu-ibu untuk dapat memberikan imunisasi dasar lengkap di Posyandu yang telah bekerja sama dengan tenaga kesehatan seperti dokter dan bidan.Terdapat 5 responden $(8,33 \%)$ telah mengakui mendapat penyuluhan mengenai imunisasi dasar lengkap, tetapi tidak membawa bayinya untuk imunisasi dikarenakan alasan bahwa bayinya sedang panas tinggi saat itu.Terdapat juga ibu yang tergolong memberikan imunisasi dasar lengkap walaupun ia mengaku tidak mendengar penyuluhan yang diberikan diPosyandusebanyak 3 responden $(5,03 \%)$ dikarenakan ia bekerja setiap hari dan terlalu sibuk untuk ke Posyandu yang waktu pelaksanaanya dari pukul $07.30-12.00$ WIB. Ibu tersebut sadar pentingnya mengimunisasi bayinya dengan cara ia membawa langsung ke rumah sakit untuk memperoleh imunisasi dasar lengkap bagi bayinya.

Terdapat 7 responden $(11,74 \%)$ yang tergolong ibu yang tidak memberikan imunisasi dasar lengkap pada bayinya dan juga menyatakan tidak memperoleh penjelasan mengenai imunisasi dasar lengkap yang disampaikan oleh kader Posyandu. Hal ini dapat terjadi karena berbagai alasan seperti kedua orang tua dari bayi tersebut bekerja untuk memenuhi kebutuhannya setiap hari, ada acara keluarga yang daerahnya jauh sehingga tidak dapat ke Posyandu pada saat program imunisasi, tidak meyakini bahwa imunisasi dapat memberikan kekebalan tubuh pada anaknya dari berbagai penyakit berbahaya, adanya kekhawatiran anaknya akan mengalami demam tinggi kalau diberikan imunisasi.

Dari hasil analisis data menggunakan regresi logistik diperoleh $\mathrm{p}$ value $0,000<\alpha=$ 0,05 . Hal ini menunjukkan ada hubungan bermakna antara peran serta kader Posyandu dalam pemberian imunisasi dasar lengkap di wilayah perumahan Griya Interbis Indah. Hal ini 
menunjukkan keberadaan kader Posyandu yang dekat dengan masyarakat dapat menjadi motivator bagi para ibu untuk dapat memberikan imunisasi dasar lengkap bagi bayinya.

Hasil penelitian ini selaras dengan Septianingtias, Soesetijo dan Widi (2018), menyatakan bahwa dukungan kader berpengaruh pada imunisasi dasar lengkap ${ }^{10}$. Selaras juga dengan Saepudin, Rizal, dan Rusman (2017) dengan hasil penelitiannya menujukkan bahwa persepsi masyarakat terhadap Program Posyandu cukup postif, Posyandu memiliki peranan penting dalam meningkatan kualitas kesehatan ibu dan anak melalui proses pelayanan kesehatan, dan Posyandu sudah menjadi pusat informasi kesehatan masyarakat ${ }^{11}$. Sedangkan keaktifan kader dalam mengedukasi masyarakat sehingga para ibu mau membawa anaknya untuk melaksanakan imunisasi sejalan dengan penelitian Nugroho dan Nurdiana (2008), bahwa ada hubungan yang signifikan sebesar 0,000 antara pengetahuan dengan keaktifan kader Posyandu di desa Dukuh Tengah kecamatan Ketanggungan kabupaten Brebes. Ada hubungan yang signifikan sebesar 0,001 antara motivasi dengan keaktifan kader Posyandu di desa Dukuh Tengah kecamatan Ketanggungan kabupaten Brebes $^{12}$.

\section{KESIMPULAN}

Dari hasil penelitian diketahui "Ada hubungan bermakna antara peran serta kader Posyandu dalam pemberian Imunisasi Dasar Lengkapdi wilayah perumahan Griya Interbis Indah". Hal ini menunjukkan keberadaan kader Posyandu yang dekat dengan masyarakat dapat menjadi motivator bagi para ibu untuk dapat membawa anaknya untuk diberikan Imunisasi Dasar Lengkap.

\section{DAFTAR PUSTAKA}

1. Kementrian Kesehatan RI. 2019. Peraturan Menteri Kesehatan Republik Indonesia Nomor 8 Tahun 2019 Tentang Pemberdayaan Masyarakat Bidang Kesehatan.

2. Nugroho, H., Nurdiana, D. 2008. Hubungan Antara Pengetahuan dan Motivasi Kader Posyandu dengan Keaktifan Kader Posyandu di Desa Dukuh Tengah Kecamatan Ketanggungan Kabupaten Brebes. Jurnal Keperawatan vol. 2 no.1:1-8.

3. Iswarawanti, D. 2010. Kader Posyandu:Peranan dan Tantangan
Pemberdayaannya Dalam Usaha Peningkatan Gizi Anak Indonesia. Jurnal Manajemen Pelayanan Kesehatan, 13 (4): 169-173

4. Notoatdmojo, S. 2003. Pengantar Pendidikan Kesehatan dan Ilmu Perilaku Kesehatan. Yogyakarta. Penerbit Andi offset.

5. Kementrian Kesehatan RI. 2017. Peraturan Menteri Kesehatan Republik Indonesia Nomor 12 Tahun 2017 Tentang Penyelenggaraan Imunisasi.

6. Kementrian Kesehatan RI. 2018. Hasil Utama Riskesdas 2018. http://kesmas.kemkes.go.id/assets/upload/dir 519d41d8cd98f00/files/Hasil-riskesdas2018_1274.pdf (diakses 23 Maret 2020)

7. SDKI.2017. Survei Demografi dan Kesehatan Indonesia.

http://sdki.bkkbn.go.id/files/buku/2017IDHS. pdf (diakses 24 Maret 2020)

8. Survei Penduduk Antar Sensus (SUPAS). 2015. Profil Penduduk Indonesia Hasil SUPAS 2015. https://www.bps.go.id/publication/2016/11/30 163daa471092bb2cb7c1fada6/profilpenduduk-indonesia-hasil-supas-2015.html (diakses 24 Maret 2020)

9. Faldi. 2019. Sumsel Capai Target Imunisasi 2018.

https://sumselterkini.co.id/pemerintahan/sums el-capai-target-imunisasi-2018-kecuali-2kabupaten-ini/ (diakses 24 Maret 2020)

10. Septianingtyas W.R, Soesetijo A, dan Widi R. 2018. Pengaruh Dukungan Kader dalam Imunisasi Dasar Lengkap di Wilayah Kerja Puskesmas Jelbuk dan Klatakan Kabupaten Jember. Multidisciplinary Journal, 1 (1): 21 24

11. Saepudin E, Rizal E, dan Rusman A. 2017. Peran Posyandu Sebagai Pusat Informasi Kesehatan Ibu dan Anak. Record and Library Jounal, 3 (2): 201-208

12.Nugroho H A, Nurdiana D. 2008. Hubungan Antara Pengetahuan Dan Motivasi Kader Posyandu Dengan Keaktifan Kader Posyandu di Desa Dukuh Tengah Kecamatan Ketanggungan Kabupaten Brebes. FIKKes Jurnal Keperawatan, 2 (1): 1-8 
